\title{
The Dynamics of REIT Capital Flows and Returns
}

\author{
by \\ David Ling and Andy Naranjo* \\ *Department of Finance, Insurance, and Real Estate \\ Graduate School of Business Administration \\ Warrington College of Business \\ University of Florida \\ Gainesville, FL 32611-7168 \\ Phone: (352) 392-0153 \\ Fax: (352) 392-0301 \\ E-mail: Ling@ufl.edu; Andy.Naranjo@cba.ufl.edu \\ Initial draft: December 2002 \\ Revised: March 4, 2003
}

\begin{abstract}
This study examines the effects of capital flows into the REIT sector on REIT returns and, simultaneously, the effects of REIT returns on subsequent REIT capital flows. The dynamic relation between REIT capital flows and returns is estimated using vector autoregression (VAR) techniques. Unlike static regression techniques, our dynamic model produces estimates of the short-run relationships, long-run relationships, impulse response functions, and forecast variance decompositions. We find evidence that REIT equity flows are significantly positively related to the prior quarter's flows and negatively related to flows from two quarter's ago. The evidence on the responsiveness offlows to prior returns is time period specific. In the important post-1992 subperiod, REIT returns do not significantly affect REIT flows in any of the VAR model specifications. Simultaneously, REIT capital flows do appear to have a significant influence on equity REIT returns.
\end{abstract}

We gratefully acknowledge the financial support of the Homer Hoyt Institute and the Real Estate Research Institute. We also thank David Downs, Michael Giliberto, Paul Seguin, and participants at the AREUEA meetings in Washington DC for helpful comments and suggestions. 


\section{The Dynamics of REIT Capital Flows and Returns}

\section{Introduction}

There is a growing body of research that examines the dynamics of capital flows and returns in national and international stock and mutual fund markets. ${ }^{1}$ Some researchers find evidence that increases in capital flows to a sector raise asset prices, but the studies disagree on whether the effect is temporary or permanent. If the increase in asset prices is temporary, it may simply reflect "price pressure," a phenomenon that has been documented for mutual fund flows and broad stock market indices. However, if the price increase is permanent, it may reflect a structural decrease in the sector's cost of equity capital. Researchers have also examined the impact of recent asset returns on subsequent capital flows to determine whether investors pursue "return chasing" or "momentum" investment strategies in addition to, or in place of, the portfolio rebalancing activity we would expect to see when the relative values of competing asset classes are altered.

This paper examines the interrelationships and short and long-run dynamics among capital flows to the REIT sector and REIT returns. In particular, our research examines whether REIT capital flows impact REIT prices and returns and whether the effect is temporary or permanent. This analysis allows us to assess the validity of both the price pressure hypothesis and the permanent change in the cost of capital hypothesis in the context of the securitized commercial real estate market. Simultaneously, we examine whether REIT returns influence capital flows into the REIT sector.

The general literature on capital flows suggests that, in addition to past returns, other variables, such as dividend yields and interest rates, may affect flows. Thus, we also investigate the extent to which other sector specific and macroeconomic variables affect the dynamic relation between REIT capital flows and returns. Finally, we examine whether the structural change that is widely acknowledged to have occurred in the REIT market during the early 1990s caused a permanent, or at least a long-lasting change, in the dynamic relation between flows and returns.

\footnotetext{
${ }^{1}$ See for example, Choe, Kho and Stulz (1999), Clark and Berko (1997), Edelen and Warner (2001), Edwards and Zhang (1998), Karceski (2003), Froot, O'Connell and Seasholes (2001), Stulz (1999), and Warther (1995, 1998).
} 
The main tool of analysis we employ is a vector autoregression (VAR) model. In addition to quantifying the relation between capital flows and returns, the VAR model allows us to estimate impulse response functions for the variables of interest. These impulse response functions provide the time path of the short-run dynamic relationships that result from a shock to the variables in the system, while the forecast variance decompositions provide the forecast error variance explained by variations in the variables.

Our results can be summarized as follows. First, we find evidence that REIT equity flows are significantly positively related to the prior quarter's flows and negatively related to flows from two quarter's ago. We also find that REIT equity flows are positively related to prior returns, suggesting that REIT investors may follow momentum trading strategies. However, the pre-1993 subperiod results differ from the post-1992 subperiod results in several important respects. First, post-1992 returns do not significantly affect REIT flows in any of the model specifications. Thus, there is no evidence (in our quarterly data) that investors engage in return chasing behavior during the post-1992 subperiod. Second, and somewhat surprisingly, post-1992 equity REIT flows do appear to influence subsequent REIT returns. As robustness checks, we also estimated structural VARs (i.e., restricted VARs) and VEC models. These results are qualitatively very similar to the VAR model estimates.

The paper proceeds as follows. In Section II we discuss the relevant literature. In Section III we describe our data sources and provide a discussion of the descriptive statistics. Section IV contains a detailed analysis of REIT capital flows since 1979, including the univariate evidence on the comovement between REIT flows and REIT returns. In Section V we describe the methodology we employ to examine the conditional covariation of flows and returns, while in Section VI we present the unrestricted VAR results using three models: a bivariate model, a fourfactor model, and a seven-factor model. In Section VII, we provide some additional robustness checks using alternative flow measures, a restricted VAR model, and a VEC model. Our conclusions are presented in Section VIII.

\section{Related Literature}

One of the most frequently investigated questions in the general finance literature is whether exogenous shocks in the demand for financial securities affect their market valuations. 
The efficient market hypothesis implies, as discussed by Gomphers and Lerner (2000) and stated by Myron Scholes, that "the shares a firm sells are not unique works of art but rather abstract rights to an uncertain income stream for which close counterparts exist either directly or indirectly." The practical implication of this assertion is that the supply curve for publicly traded financial assets is perfectly elastic_-even in the short run. Thus, stock prices are determined solely by the firm's marginal cost of equity capital—shifts in investor demand and the volume of transactions are irrelevant.

The assertion that supply curves for financial securities are perfectly elastic has inspired numerous theoretical and empirical analyses. Although each of these studies has its shortcomings, some suggest that capital flows have a real impact on valuations and returns. For example, in the context of emerging markets, Bekaert et al. (2002), Froot et al. (2001) and Clark and Berko (1997) find that increases in capital flows raise stock prices, although the studies do not agree on whether the price effect is temporary or permanent. Tesar and Werner (1995a, b) and Brennan and Cao (1997) also find evidence of positive, contemporaneous correlation between international portfolio flows and returns.

There have also been a number of studies that have examined the linkages between mutual fund flows and returns. Warther $(1995,1998)$ reports a strong contemporaneous relation between fund flows and returns, but no evidence that flows affect subsequent returns. Remolona et al. (1997) and Edwards and Zhang (1998) also find no evidence that mutual fund flows affect subsequent returns. Similarly, Cha and Lee (2001) conclude that capital flows do not Granger Cause returns directly in the presence of market fundamentals, although flows seem to affect returns through revisions in the expected future cash flows and returns. In contrast, Edelen and Warner (2001) find a positive correlation between unexpected aggregate mutual fund flows and concurrent excess returns. However, there appears to be little evidence of non-contemporaneous correlation between mutual fund flows and returns. $^{2}$

Finally, there is some evidence in other asset markets that investor flows affect prices. For example, using venture fund capital flows, Gompers and Lerner (2000) find a strong positive relation between inflows into private equity funds and the estimated value of such funds. Froot and O’Connell (1997) provide similar evidence for the catastrophe risk-bearing industry.

\footnotetext{
${ }^{2}$ A number of these capital flow papers are summarized by Clayton (2003).
} 
The second, and related, hypothesis of interest is whether asset returns affect subsequent capital flows. Warther $(1995,1998)$ and Remolona et al. (1997) find no relation between mutual fund returns and subsequent flows. In contrast, Edwards and Zhang (1998), Fortune (1998), Cha and Lee (2001), Karceski (2003), and Edelen and Warner (2001) conclude that mutual fund returns do affect subsequent capital flows into the sector. Sirri and Tufano (1998) also find evidence that mutual fund investors chase returns, flocking to funds with the highest recent returns, although the evidence suggests investors are slow to sell poor performing funds. In an emerging markets context, the analysis presented by Bohn and Tesar (1996) provides partial support for the return-chasing hypothesis.

If the unconditional evidence suggests a causal link between capital flows and returns, it is important to note that there exists an alternative explanation for the relation -- flows and returns are not causally linked, but rather respond to common information. That is, capital inflows and outflows do not move prices. Rather, flows merely reflect the underlying state of fundamental economic variables (Froot et al., 2001). For example, in a commercial real estate context, Ling and Naranjo (1997) find that, in addition to systematic market risk, unexpected inflation and real interest rates drive expected returns. REIT capital flows may simply react to changes in these same variables.

\section{Data and Descriptive Statistics}

\section{Data Sources}

Our sample period begins in the first quarter of 1979 and ends in the second quarter of 2002. The data on quarterly REIT capital flows come from two sources. First, from the National Association of Real Estate Investment Trusts (NAREIT), we obtain the total dollar value of new equity capital raised by REITs. Equity issues include initial public offerings (IPOs) and secondary offerings of common or preferred stock. These "gross" equity flows serve as a benchmark for our measures of net REIT equity flows.

Our second source of REIT capital flow data is the Federal Reserve Board's quarterly Z.1 statistical release "Flow of Funds Accounts of the United States." From this source, we abstract two time series. The first is net equity issues, defined as the difference between gross equity 
issuance (a positive source of REIT funds) and equity retirements (a negative source of funds). ${ }^{3}$ The second time series obtained from the Flow of Funds Accounts is the net increase in REIT liabilities. This measure includes net equity issuance, plus net debt issuance and the change in miscellaneous liabilities. Because this second measure captures the net change in all sources of REIT capital, we refer to it below as "total" REIT flows. We also obtain from the Flow of Funds Accounts the corresponding time series on U.S. corporate equity flows (minus REITs) and corporate and foreign bond flows.

The quarterly frequency of our flow data is not without its drawbacks. In particular, quarterly data make it more difficult to uncover short-term price and flow effects. Use of the Fed flow data, however, does provide a significant benefit relative to the numerous studies that have employed mutual fund flow data. In particular, the Fed flow data capture all capital flows into, and out of, the U.S. REIT and corporate equity markets, not just mutual fund flows. The ability to capture total capital flows in a sector is clearly an advantage when attempting to discern whether capital flows affect returns and visa versa. In addition, the use of quarterly data reduces significantly the probability of a Type I error. If we uncover statistically significant covariation between flows and returns, it is likely that we would also be able to reject the null hypothesis of no covariation using higher frequency data.

We obtain historical REIT returns and dividend yield premiums (relative to 10-year Treasury securities) from NAREIT, while the stock market returns, dividend yields, and US longterm government bond returns are taken from the Center for Research in Securities Pricing (CRSP) database and the Ibbotson databank. We obtain quarterly Fama-French systematic risk factors from Ken French. ${ }^{4}$

\section{Descriptive Statisitcs}

Univariate descriptive statistics for the variables used in our regression analyses are presented in Table 1. We report statistics for the full sample period as well as two subperiods:

\footnotetext{
${ }^{3}$ A complete description of the accounts is available in Guide to the Flow of Funds Accounts, Board of Governors of the Federal Reserve System, Washington, D.C. The Z.1 statistical release is available in printed form and on the Board's public web site at www.federalreserve.gov/releases/Z1.

${ }^{4}$ These factors are the excess return on a broad market portfolio $\left(\mathrm{R}_{\mathrm{MKT}}\right)$, the difference between the return on a portfolio of small stocks and the return on a portfolio of large stocks (SMB, small minus big), and the difference between the return on a portfolio of high-book-to-market-equity stocks and the return on a portfolio of low-book-to market-equity stocks (HML, high minus low). See Fama and French (1996) for some additional details.
} 
1979(Q1) to 1992(Q4) and 1993(Q1) to 2002(Q2). Net REIT equity flows averaged \$1.4 billion per quarter over the full sample period. During the pre-1993 period, however, equity flows averaged just $\$ 0.348$ billion, while during the post-1992 period the quarterly average was $\$ 3.1$ billion. The volatility of net flows, as measured by the standard deviation, is quite high, especially given the quarterly frequency of the data. Despite the significantly larger flows in the second subsample, flows as a percentage of REIT stock market capitalization were considerably lower than in the pre-1993 period, averaging 6.0 percent. The corresponding percentage in the pre-1993 period was 15.4 percent. A similar pattern is observed in total (debt \& equity) capital flows.

Because REITs are income-oriented stocks, the dividend yield spread is frequently mentioned in professional publications as an important determinant of investor demand for REIT stocks. ${ }^{5}$ However, to our knowledge, there exists no empirical confirmation of the importance of dividend yield spreads. The use of the dividend yield spread in our analysis is also motivated by the work of Bekaert and Harvey (2002), who argue that in a rational pricing model, dividend yields will be decreasing in the growth rate of dividends and increasing in the discount rate. Therefore, dividend yields may be useful in capturing permanent price effects induced by a change in the firm's cost of capital. To examine the explanatory power of dividend yield spreads, we include the NAREIT yield spread ( YLDSP $\left._{\text {REIT }}\right)$ in our analysis. YLDSP REIT $_{\text {, defined }}$ as the NAREIT dividend yield minus the contemporaneous yield on 10-year Treasury securities, averaged -0.70 percentage points over the full sample. This reflects an average of -1.87 percentage points in the pre-1993 period and 1.07 percentage points in the second subsample.

Since available investment capital (wealth) at any point in time is somewhat constrained, it is possible that capital flows into, and out of, corporate equities and bonds may affect REIT capital flows. Flows into the combined U.S. corporate equity and bond markets ( $\left.\mathrm{F}_{\mathrm{CORPBONDS}}\right)$ averaged $\$ 53.5$ billion per quarter over the full sample and $\$ 100$ billion in the second subperiod. These quarterly flows amounts are 13 and 12 times, respectively, larger than the corresponding total REIT flows.

\footnotetext{
${ }^{5}$ See, for example, Barry Vinocur, “Taking Stock,” Realty Stock Review, November 22, 2002, p. 9.
} 
To control for time variation in returns due to "systematic risk factors," we also include the Fama-French factors ( $\mathrm{R}_{\mathrm{MKT}}$, $\mathrm{SMB}$, and $\left.\mathrm{HML}\right)$ in subsequent, expanded specifications of our analysis.

\section{The Behavior of REIT Capital Flows}

Panel A of Figure 1 displays the quarterly gross issuance of REIT equity capital since 1979, measured in billions of 2001(Q4) dollars. Although the REIT industry was created by Congress in 1960, by year-end 1978 (the beginning of our sample period) the total stock market capitalization of the industry was just $\$ 1.4$ billion. During the next 14 years an additional $\$ 17.1$ billion in equity securities were issued by REITs, bringing the industry's stock market capitalization to $\$ 15.9$ billion. During this pre-1993 period, REITs were largely passive investment vehicles that owned diverse portfolios of properties.

As is discussed by Capozza and Seguin (2003) and others, the creation of the UPREIT (umbrella partnership REIT) structure, along with several other regulatory and economic factors, precipitated a boom in REIT equity flows as 95 IPOs came to market in 1993 and 1994. As displayed in panel A of Figure 1, the REIT IPOs boom peaked in the fourth quarter of 1993 with $\$ 5.6$ billion in initial equity offerings. Thus began the "modern" REIT era. ${ }^{6}$

Panel A of Figure 1 also reveals that gross equity flows declined in 1995 and 1996 from their 1993(Q4) peak, but then increased sharply again in 1997 and early 1998. This second wave of REIT equity flows peaked in the fourth quarter of 1997, during which $\$ 11.6$ billion in equity was issued. By year-end 1997, the stock market capitalization of the REIT industry had reached \$141 billion. REIT equity offerings decreased significantly from this 1997(Q4) peak with just $\$ 9.6$ billion coming to the market in 1999 and 2000 . However, issuance activity picked up again in late 2001 and early 2002. By the end of the second quarter in 2002, the market capitalization of the REIT industry had reached $\$ 171.2$ billion. REIT equity flows, net of retirements, are displayed in panel B of Figure 1. These net equity flows exhibit the same clustering observed with gross equity issuances. In fact, the correlation between the gross and net quarterly series is 0.978 .

\footnotetext{
${ }^{6}$ For an extended discussion of the 1993-94 REIT IPO boom, see Ling and Ryngaert (1997).
} 
Total REIT capital flows in 2001(Q4) dollars, including the net issuance of both debt and equity securities, are displayed in panel $\mathrm{C}$ of Figure 1. Although the total flow magnitudes are significantly larger than the equity flows depicted in panels A and B (the vertical scale in panel C ranges to a maximum of $\$ 40$ billion per quarter), the time series pattern is very consistent with that of equity flows. In fact, the correlation between net equity flows (panel B) and total flows (panel C) is 0.905 , suggesting that debt offerings have tended to supplement, not replace, equity offerings. Further evidence of the clustering patterns observed in Figure 1 is revealed by the first order autocorrelations of the three time series: gross equity flows; 0.882 , net equity flows; 0.888 , and total flows; 0.851. Clearly, REIT capital flows exhibit significant persistence from quarter to quarter.

Cumulative REIT capital flows are displayed graphically in Figure 2. Cumulative total flows, in 2001(Q4) dollars, reached $\$ 332.7$ billion by 2002(Q2). In contrast, cumulative net flows and cumulative gross flows reached $\$ 118.3$ billion and $\$ 120.6$ billion, respectively, by 2002(Q2). As a result of the 0.978 correlation between these two series of equity flows, the plot of cumulative gross equity flows in Figure 2 cannot be distinguished from that of cumulative net equity flows. Cumulative total returns on the NAREIT Index are also included in Figure 2, with the vertical scale on the right side of the graph representing the cumulative value of $\$ 1$ invested at the beginning of the study period. A dollar invested in the NAREIT index would have accumulated to $\$ 15.37$ by $2002(\mathrm{Q} 2)$.

Given that the flow variable of primary interest in our regression analysis is net equity flows, it is interesting to ask whether the data in Figure 2 provide any evidence on the relation between flows and returns. While these results are unconditional, they do suggest that net equity flows and REIT share prices move together at quarterly frequencies. Froot et al. (2001) and SaAadu and Shilling (2002) argue that this co-movement could be ascribed to a variety of factors, including overreaction, information shocks, or demand shocks. For example, REITs may be forced into a financing pecking order in which they issue new equity only after internal funds and debt capacity have been exhausted (see Myers, 1984). Another possible explanation for the comovement between flows and returns is that because REITs are required to pay out the majority of their taxable income as dividends each year, the issuance of equity may simply be motivated by the arrival of positive NPV investment projects (Ambarish, John, and Williams, 
1987). Information shocks provide a third explanation for the clustering of equity issuance. For example, if one REIT goes public this may provide a positive signal about the industry's prospects, thereby motivating other similar firms to pursue IPOs or issue additional equity shares (Stoughton, Wong, and Zechner, 2000). An additional explanation is based on models of overreaction and "hot markets." In particular, REIT managers may seek to cluster their equity issues during periods in which investors are perceived to be overly optimistic (Helwege and Liang, 1996, and Rajan and Servaes, 1997).

Since we investigate the dynamic behavior of REIT flows and returns, it is important to consider the appropriate measure of REIT capital flows. In addition to distinguishing between equity flows and total (equity plus debt) flows, Froot et al. (2001) argue that the impact of capital flows in period $t$ on returns is conditional on the size of the market in period $t-1$. Based on this argument, we create an additional flow variable for use in our regressions. In particular, we define $\mathrm{RELF}_{\mathrm{REIT}}$ as the net equity flow in quarter $t$ relative to the total market capitalization of the REIT industry at the end of quarter $t-1$.

The significance of weighting equity cash flows by market capitalization is revealed in Figure 3. Net equity flows in billions of dollars, depicted on the left vertical axis, are seemingly not distinguishable from zero during the early years of the sample period. Although small in absolute terms, as a percent of REIT equity market capitalization (measured on the right vertical axis) these flows were significant during the early years of the study period. After reaching a low in 1984(Q2), equity flows increased in 1985. Although flows in 1985-86 never exceeded \$3.5 billion in 2001 dollars, they were large relative to the market capitalization of the industry. The wave of equity issuance that occurred in 1993-94 was significant in absolute terms, but relative to the industry's market capitalization it was less significant than the $1985-86$ period. The potential importance of conditioning flows on market size is also evident in 1997-98 when equity flows reached historical levels. However, relative flows were actually smaller than during the two prior periods of significant equity issuance.

We plot REIT equity flows, as a percentage of market capitalization, in Figure 4, along with quarterly NAREIT total returns. In Table 2, we report the correlations among the various variables over the three sample periods. For the full sample period we observe a positive correlation of 0.214 between equity REIT flows relative to market capitalization (RELF REIT $_{\text {) and }}$ 
equity REIT returns ( $\left.\mathrm{R}_{\mathrm{REIT}}\right)$. Interestingly, the correlation between unadjusted equity REIT flows $\left(\mathrm{F}_{\mathrm{REIT}}\right)$ and returns is negative over the full and pre-1993 sample periods and only 0.024 in the post-1992 sample period. Not surprisingly, REIT returns are positively correlated with both $\mathrm{R}_{\mathrm{MKT}}$ and SMB (i.e., correlation of 0.560 and 0.490 respectively). The magnitude of the correlations during the pre-1993 and post-1992 subperiods (see Panels B and C) largely mirror those reported for the full sample.

Although Figure 4 and the correlation results in Table 2 may be suggestive of a relation between REIT flows and returns, they do not imply causation in any meaningful sense. To get a preliminary sense of the relation between REIT capital flows and returns, we performed Granger Causality tests over the three sample periods. ${ }^{7}$ Over the full and pre-1993 sample periods, the null that REIT returns do not Granger Cause subsequent REIT flows is rejected at the 5\% significance level, while we cannot reject the null that REIT flows do not Granger Cause REIT returns over these same sample periods. For the post-1992 sample period, however, the Granger Causality results are reversed in that we reject the null that REIT flows do not Granger Cause REIT returns and cannot reject the null that REIT returns do not Granger Cause REIT flows at 5\% significance level. Overall, the Granger Causality results suggest that the relationship between REIT flows and returns is time period specific.

\section{The Interaction Between Flows and Returns}

In the previous section, we provided univariate, graphical, and correlation evidence on the comovement between Equity REIT flows and REIT returns during three time periods: 1979(Q1)2002(Q2), 1979(Q1)-1992(Q4), and 1993(Q1)-2002(Q2). Although these unconditional results suggest a relation between capital flows and returns, they do not clearly depict the structure of the relation and do not control for other factors that are likely to influence flows and returns. We seek to answer two questions in this section. First, do flows predict returns over and above the predictions of lagged returns? Second, do returns predict flows over and above the predictions of lagged flows? To address these questions we would prefer to base our analysis on an economic theory that captures the dynamic relation between capital flows and returns. Given the absence

\footnotetext{
${ }^{7}$ It is important to note that Granger Causality measures precedence and information content, but does not by itself indicate causality in the more common use of the term.
} 
of such a theory, we rely on vector autoregressions (VARs) to characterize the behavior of important variables.

In its simplest form, a VAR model is composed of a system of regressions in which a set of dependent variables are expressed as linear functions of their own and each other's lagged values, and possibly some other independent variables. For example, without loss of generality, consider the following two-variable, one-period lag VAR model:

$$
\begin{aligned}
& Y_{t}=a_{1}+b_{1} Y_{t-1}+c_{1} Z_{t-1}+e_{1 t} \\
& Z_{t}=a_{2}+b_{2} Z_{t-1}+c_{2} Y_{t-1}+e_{2 t} .
\end{aligned}
$$

This style of simultaneous equation modeling was introduced by Sims (1980) and has proven to be especially useful for forecasting systems of interrelated time series variables. In more technical terms, a vector autoregression model is the unconstrained reduced form of a dynamic simultaneous equations model.

In general terms, an unrestricted $\mathrm{p}^{\text {th }}$-order Gaussian VAR model can be represented as: $Y_{t}=\mu+\Phi_{1} Y_{t-1}+\Phi_{2} Y_{t-2}+\ldots+\Phi_{k} Y_{t-p}+e_{t}$, where $\mathrm{Y}_{\mathrm{t}}$ is a vector of variables, $\mu$ is a $p \times 1$ vector of intercepts, $\Phi_{1}, \Phi_{2}, \ldots, \Phi_{\mathrm{k}}$ are $p$ x $p$ matrices of parameters with all eigenvalues of $\Phi$ having moduli less than one so that the VAR is stationary, and $e_{t}$ is a vector of uncorrelated structural shocks $[\sim N I D(0, \Omega)]$. In a bivariate framework of only flows and returns, the diagonal coefficients of $\Phi$ represent conditional momentum in flows and returns, while the off-diagonal coefficients of $\Phi$ represent conditional positive feedback trading (flows following returns) and conditional anticipation effects (returns following flows). The off-diagnol elements of $\Omega$ capture the price-impact effect of flows on returns.

We obtain maximum likelihood estimates of $\Phi$ and $\Omega$ using iterated least squares. The lag-length of the VAR is chosen by looking at the AIC and the likelihood ratio for various choices of $p$. We also use the estimates of $\Phi$ to form impulse response functions, which provide the time path of the short-run dynamic relationships from a shock to the variables in the system. In particular, we compute impulse responses from a one standard deviation flow shock and examine the effects on flows and returns. We then compute impulse responses from a one standard deviation return shock and examine the effects on flows and returns. Finally, we 
examine the forecast variance decompositions from the system to provide the forecast error variance explained by variations in the variables.

As a robustness check on the unrestricted VAR models, we also examine various restricted VAR models. In particular, we estimate structural VAR models in which we impose various structural assumptions about the causality of flows and returns (see Section VII). Because a problem arises with the VAR framework if the variables in the system are non-stationary, as an additional robustness check we also examine vector error-correction (VEC) models in cases where the data are nonstationary. Our VEC methodology is discussed in detail in the appendix.

\section{Unrestricted Vector Autoregressive Results}

In this section, we examine the conditional covariation results using three unrestricted VAR models: a bivariate model, a four-factor model, and a seven-factor model. The bivariate model consists of equity REIT flows and returns. Although the regression coefficients from the bivariate model provide useful summary information, they are univariate relations, which may obscure some dynamic patterns. For example, there may be a positive relation between current capital flows and future returns, but part of this correlation may come indirectly through the effect of interest rates on capital flows. With our four-factor model we seek to determine whether the relations we uncover in our bivariate model exist after controlling for interest rates and dividend yield spreads. As previously discussed, the dividend yield spread is frequently hypothesized to be an important determinant of investor demand for REIT stocks. Finally, we also estimate a seven-factor model that also includes the Fama-French factors $\left(\mathrm{R}_{\mathrm{MKT}}\right.$, $\mathrm{SMB}$, and HML), which have been found to have an influence on equity REIT returns (Karolyi and Sanders, 1998). The results from these three models provide conditional evidence on the influence of returns on flows, and vice versa, as well as the dynamics of the relationship.

In Table 3, we report VAR model estimates for the full sample period. The data support the use of 2 quarterly lags for each of the specifications. Looking first at the equity REIT flow equation $\left(\mathrm{RELF}_{\mathrm{REIT}}\right)$ estimates, we find that for each of the VAR specifications contemporaneous flows are significantly positively related to the prior quarter's flows and negatively related to flows from two quarter's ago. These results suggest positive momentum in REIT flows, but this momentum reverses after two quarters. We also find that REIT equity flows are positively 
related to prior returns with a two-quarter lag, suggesting that REIT investors may follow momentum strategies. This results, however, is substantially weaker in the four-factor and seven-factor models. Turning to the REIT return equations ( $\left.\mathrm{R}_{\mathrm{REIT}}\right)$, we find that equity REIT flows do not significantly influence returns in any of the three specifications.

Table 4 provides conditional covariation estimates between equity REIT flows and returns using pre-1993 data. Similar to the full sample period results, equity REIT flows are positively related to flows in the prior quarter, but inversely related to flows in quarter $t-2$. This reversal of signs over the two quarters is consistent with an overshooting of flows and a consequent reversion of those flows. ${ }^{8}$ We again find that REIT flows are positively related to returns from two quarters ago, although this effect is not statistically significant in the four- and seven-factor model specifications.

In Table 5, we provide the unrestricted VAR model estimates for the 1993(Q1)-2002(Q2) period. As discussed earlier, this period is potentially of greatest interest because the modern REIT era is widely believed to have begun in 1992 or 1993. Ignoring this apparent structural change could complicate our empirical analysis because it may have caused permanent, or at least long-lasting, changes in the data generating process.

Looking first at the flow equation estimates, we again find that equity flows exhibit momentum, with a reversal after two quarters. However, in contrast to the results reported for the full and pre-1993 sample periods, REIT returns in the post-1992 sample period do not significantly affect REIT flows in any of the VAR model specifications. Also in contrast to the full and pre-1993 sample period results, equity REIT flows have a significant influence on equity REIT returns. More specifically, prior quarter flows increase contemporaneous REIT returns, whereas the effect is negative for two quarters ago, suggesting the flow effect on returns has a temporary component.

In Figure 5, we plot the impulse responses of a generalized one standard deviation innovation in equity REIT flows and returns on both flows and returns. ${ }^{9}$ The impulse responses

\footnotetext{
${ }^{8}$ An ARMA $(1,1)$ also fits the flow data, but an AR(2) provides a better diagnostic fit. An MA(1) does not fit the data very well.

${ }^{9}$ As described in Pesaran and Shin (1998), generalized impulses do not depend on the VAR ordering. However, as a robustness check, we also examined various Cholesky orderings and obtained similar results.
} 
are based on the seven-factor unrestricted VAR model estimates during the 1993(Q1)-2002(Q2) post sample period. The impulse responses provide several interesting results. First, the top left graph depicts the response of equity flows to a flows shock and suggests that the persistence of flows is pronounced, with a shock resulting in a large initial flow increase, reaching its maximum two quarters later and then gradually dissipating over eight quarters. Second, a one standard deviation return shock (top right) produces a three quarter increase in flows, which dissipates to zero thereafter. When we shock flows we find a temporary increase in REIT returns, which then dissipate to zero after three quarters (bottom left). Finally, a shock in equity REIT returns has a pronounced effect on equity REIT returns in the subsequent period, but the influence quickly dissipates to zero in the next quarter.

In Panels A and B of Table 6, we report the variance decomposition of equity REIT flows and returns, respectively. In Panel A, we document that in the first period of the forecast horizon for equity REIT flows, $100 \%$ of the squared prediction error in flows is explained by variation in flows. At horizons up to eight quarters, flows explain about $79 \%$ of the forecast error variance. Interestingly, the NAREIT yield spread, U.S. long-term government bond returns, and FamaFrench's SMB factor explain about $15 \%$ of the variance. Turning to Panel B, we document that in the first period of the forecast horizon for equity REIT returns, flows explain $14 \%$ of the variation and returns explain the remainder. At horizons up to eight quarters, equity flows, the NAREIT yield spread, and the $\mathrm{R}_{\mathrm{MKT}}$ explain approximately $30 \%$ of the variation.

\section{Robustness Checks, Restricted VAR Models, and VEC Models}

We also performed various robustness checks on the conditional relationship between REIT flows and returns. In particular, to assess if relative capital flows across market sectors influence REIT returns, we re-specified each of the models with an alternative flow measure defined as total REIT flows (i.e., equity plus debt, TOTF $_{\text {REIT }}$ ) divided by total corporate equity and bond flows minus REITs ( $\left.\mathrm{F}_{\mathrm{CORPBONDS}}\right)$. Although not reported, the total relative crossmarket flow measure was insignificant in each specification. If we include both total REIT flows relative to total market flows and equity REIT flows relative to equity REIT capitalization together in each of the specifications, we again find that REIT flows relative to capitalization are 
significant, whereas total REIT flows relative total market flows are insignificant. These results suggest that REIT flows relative to the size of the market are more important than relative crossmarket REIT flows in influencing REIT returns. ${ }^{10}$

As additional robustness checks, we also estimated structural VARs (i.e., restricted VARs) and VEC models. In our estimation of the structural VARs, we impose the identifying restriction that current REIT returns are related to current flows as well as to both past returns and flows. This assumption would hold if market makers perceive current flows to contain information about value. We find that current flows are highly significant in explaining current returns (coefficient estimate of 0.87 with a t-statistic $=2.97$ ). Similar to our earlier reported findings, we also find that flows exhibit positive momentum, with a two-quarter reversal (coefficient estimates of 1.13 and -0.33 with t-statistics of 7.27 and -2.25 respectively).

As discussed earlier, a potential problem arises with the VAR framework if the variables in the system are non-stationary. Therefore, to assess the stationarity of the variables, we also performed both Dickey-Fuller and Phillips-Perron unit root tests (with and without trends). In each case, we could not reject the null hypothesis of a unit root at the 5\% significance level for the REIT flow data during the post-1992 period. Using Johansen's (1988) method, we first obtained the number of cointegrating vectors (rank of $\Pi$ ) and then the parameter estimates using the VEC model. The results of Johansen's (trace) cointegration tests during the 1993(Q1)2002(Q2) sample period indicate the existence of one cointegrating vector. Though not reported, the results from the VEC model with the cointegrating vector suggest that there is a long-run positive relation between flows and returns in the post-1992 era, with a ten percent increase in relative flows increasing returns by approximately 0.5 percent in the long run. These "long-run" results, however, should be viewed cautiously given the relatively small sample in the post-1992 era. The short-run dynamics from the VEC estimates in the post-1992 era are also very similar to

\footnotetext{
${ }^{10}$ As an additional robustness check on the influence of REIT flows on returns, we also separated REIT flows into expected and unexpected components. In particular, as a first-pass, we regressed REIT flows on lagged REIT flows, lagged REIT returns and the additional variables from our seven-factor model specification. As a second-pass, we then regressed REIT returns on the expected and unexpected components of REIT flows from the first-pass. We found that the REIT returns were affected by the unexpected REIT flows, whereas expected REIT flows had no affect on REIT returns. However, it is important to note that these decomposition results are very noisy and the precise measurement of appropriately signed expected and unexpected flows is problematic given the quarterly frequency of the flow data.
} 
the VAR model estimates reported earlier. In particular, prior quarter flows increase contemporaneous REIT returns, whereas the effect is negative for two quarters ago.

\section{Conclusion}

This paper examines the interrelationships and short and long-run dynamics among capital flows to the REIT sector and REIT returns. In particular, our research examines whether REIT capital flows impact REIT prices and returns and whether the effect is temporary or permanent. Simultaneously, we examine whether past REIT returns influence current capital flows into the REIT sector.

Our sample period begins in the first quarter of 1979 and ends in the second quarter of 2002. The main tool of analysis is vector autoregression (VAR). This technique allows us to estimate impulse response functions for the variables of interest. These impulse response functions provide the time path of the short-run dynamic relationships that result from a shock to the variables in the system, while the forecast variance decompositions provide the forecast error variance explained by variations in the variables. We estimate three unrestricted VAR models: a bivariate model, a four-factor model, and a seven-factor model. The bivariate model consists of equity REIT flows and returns. The four-factor model also includes interest rates and the NAREIT dividend yield spread as exogenous variables. Our seven-factor model also includes the Fama-French risk factors ( $\mathrm{R}_{\mathrm{MKT}}, \mathrm{SMB}$, and $\mathrm{HML}$ ), which have been found to have an influence on equity REIT returns.

Our results can be summarized as follows. First, we find that for each of the VAR specifications contemporaneous REIT equity flows are significantly positively related to the prior quarter's flows and negatively related to flows from two quarter's ago. These results suggest there is positive momentum in REIT flows, but this momentum reverses after two quarters. Interestingly, we also find that REIT equity flows are positively related to prior returns with a two-quarter lag, suggesting that REIT investors may follow momentum trading strategies. The return momentum effect on REIT equity flows, however, becomes substantially weaker in the four-factor and seven-factor models. We find that equity REIT flows in quarter $t$ do not significantly influence REIT returns in quarter $t+1$ in the full sample. 
Because significant structural changes occurred in the REIT industry in the early 1990s, we reestimated our three VAR models using data from two subperiods: 1979(Q1) to 1992(Q4) and 1993(Q1) to 2002(Q2). Similar to the full sample results, we find that equity REIT flows in the pre-1993 period are positively related to flows in the prior quarter, but inversely related to flows in quarter $t$-2. We again find that REIT flows are positively related to returns from two quarters ago, although this effect is significantly attenuated in the four- and seven-factor model specifications. In the post-1992 subperiod, we replicate the results that equity flows exhibit momentum, with a reversal after two quarters. However, in contrast to the full and pre-1993 sample periods, returns do not significantly affect REIT flows in any of the VAR model specifications. Also in sharp contrast to the full and pre-1993 sample results, equity REIT flows appear to have a significant influence on subsequent REIT returns.

As robustness checks, we also used alternative REIT flow measures and estimated structural (restricted) VARs and vector error correction (VEC) models. The alternative flow measure results suggest that REIT flows relative to the size of the market are more important than relative cross-market REIT flows in influencing REIT returns. In our estimation of the structural VARs, we impose the identifying restriction that current REIT returns are related to current flows as well as to both past returns and flows. These estimates suggest that current flows are highly significant in explaining current returns. Similar to our earlier reported findings, we also find that flows exhibit positive momentum, with a two-quarter reversal. The results from the VEC model are qualitatively very similar to the VAR model estimates.

There are some caveats to our analysis. First, we would prefer to base our analysis on an economic theory that captures the dynamic relation between capital flows and returns. However, in the absence of such a theory, we must rely on vector autoregressions to characterize the behavior of important variables. Second, the quarterly frequency of our flow data limits our ability to uncover monthly or weekly price and flow effects. Higher frequency data would also allow for greater precision in determining contemporaneous versus non-contemporaneous components of covariance. Therefore, one possible extension of this work would be to use flow data for REIT mutual funds, which are available at higher frequencies. However, unlike the Federal Reserve Board flow data that we employ, REIT mutual fund flow data capture only a sub-sector of all capital flows into, and out of, the U.S. REIT market. 


\section{Appendix}

In general, a series is non-stationary if its mean, autocovariances, or other higher moments are time dependent. For example, if the mean of a series varies with respect to time, it is likely to be non-stationary. Simply stated, the test for a unit root (i.e., non-stationarity) in a time-series is the test that a regression of a series on itself lagged one period yields a coefficient of one. This test is complicated by several features arising from the non-stationarity of the series under the null hypothesis. In a well-known paper, Dickey and Fuller (1979) suggest a method for computing a test for a unit root in a time-series. Since then, a large literature on unit root tests has appeared with alternative tests that are generally variations of the Dickey-Fuller test.

A vector error-correction (VEC) model is similar to a VAR model, except the VEC model is designed for use with non-stationary time series (see, for example, Hamilton, 1994). In particular, the VEC model is more appropriate if the variables in the VAR system are integrated of order one or more (i.e., are non-stationary). In this case, the VAR estimates and inferences drawn from them are subject to the problems of regressions involving non-stationary variables. The VEC model, on the other hand, is a restricted VAR model designed for use with nonstationary series that are cointegrated. A group of non-stationary time series is cointegrated if there is a linear combination of them that is stationary. These cointegrating relations are incorporated into the VEC. For example, consider the following two-variable VEC with nonstationary time series:

$$
\begin{aligned}
& \Delta \mathrm{Y}_{\mathrm{t}}=\mathrm{a}_{1}+\mathrm{b}_{1} \Delta \mathrm{Y}_{\mathrm{t}-1}+\mathrm{c}_{1} \Delta \mathrm{Z}_{\mathrm{t}-1}+\alpha_{1}\left(\mathrm{Y}_{\mathrm{t}-1}-\beta \mathrm{Z}_{\mathrm{t}-1}\right)+\mathrm{e}_{1 \mathrm{t}} \\
& \Delta \mathrm{Z}_{\mathrm{t}}=\mathrm{a}_{2}+\mathrm{b}_{2} \Delta \mathrm{Z}_{\mathrm{t}-1}+\mathrm{c}_{2} \Delta \mathrm{Y}_{\mathrm{t}-1}+\alpha_{2}\left(\mathrm{Y}_{\mathrm{t}-1}-\beta \mathrm{Z}_{\mathrm{t}-1}\right)+\mathrm{e}_{2 \mathrm{t}},
\end{aligned}
$$

where all terms involving $\Delta$ (i.e., first differences) are stationary. This two-variable error correction model is a bivariate VAR in first differences augmented by the error-correction terms $\alpha_{1}\left(\mathrm{Y}_{\mathrm{t}-1}-\beta \mathrm{Z}_{\mathrm{t}-1}\right)$ and $\alpha_{2}\left(\mathrm{Y}_{\mathrm{t}-1}-\beta \mathrm{Z}_{\mathrm{t}-1}\right)$ from the cointegrating relation. In general, the $\mathrm{k}^{\text {th }}$ order vector error-correction model can be represented by the following system:

$$
\Delta X_{t}=\mu+\Gamma_{1} \Delta X_{t}-1+\Gamma_{2} \Delta X_{t}-2+\ldots+\Gamma_{k}-1 \Delta X_{t}-k+1+\Pi X_{t}-k+e_{t},
$$

where $\mathrm{X}_{\mathrm{t}}$ is a vector of $p I(1)$ variables, $\mu$ is a $p \times 1$ vector of intercepts, $\Gamma_{1}, \Gamma_{2}, \Gamma_{\mathrm{k}}, \Pi$ are $p \times p$ matrices of parameters, $e_{t}$ is a vector of uncorrelated structural shocks $[\sim N I D(0, \Omega)], \Delta$ is a difference operator, and $I(1)$ is integrated of order one (i.e., first-difference stationary). In the 
above VEC system, the coefficient matrix $\Pi$ provides information about the long-run relations among the variables, while the $\Gamma$ 's provide information on short-run relations. Using Johansen's (1988) method, we obtain estimates of the long-run relationships. 


\section{References}

Ambarish, R., K. John, and J. Williams. 1987. Efficient Signaling With Dividends and Investments. Journal of Finance 42: 321-344.

Bekaert, G., and C.R. Harvey. 2000. Foreign Speculators and Emerging Equity Markets. Journal of Finance 55: 565-613.

Bekaert, G., C.R. Harvey, and R. L. Lumsdaine. 2002. The Dynamics of Emerging Market Equity Flows. Journal of International Money and Finance 21: 295-350.

Bohn, H. and L.L. Tesar. 1996. U.S. Equity Investment in Foreign Markets: Portfolio Rebalancing or Return Chasing? American Economic Review 86: 77-81.

Brennan, M. and H. Cao. 1997. International Portfolio Investment Flows. Journal of Finance 52: 1851-1880.

Capozza, D. and P. Sequin. 2003. Real Estate Economics

Cha, H.S. and B. Lee. 2001. The Market Demand Curve for Common Stocks: Evidence from Equity Mutual Fund Flows. Journal of Financial and Quantitative Analysis 36: 195-220.

Choe, H., B.C. Kho, and R. Stulz. 1999. Do Foreign Investors Destabilize Stock Markets? The Korean Experience in 1997. Journal of Financial Economics 54: 227-264.

Clark, J. and E. Berko. 1997. Foreign Investment Fluctuations and Emerging Market Stock Returns: The Case of Mexico. Staff Report 24, Federal Reserve Bank of New York, New York, NY.

Clayton, J., 2003. Capital Flows and Asset Values: A Review of the Literature and Exploratory Investigation in a Real Estate Context. Unpublished Working Paper, University of Cincinnati, Cincinnati, $\mathrm{OH}$.

Dickey, D. and W. Fuller. 1979. Distribution of the Estimates for Autoregressive Time Series with a Unit Root. Journal of the American Statistical Association: 427-431.

Edelen, R. M. and J. B. Warner. 2001. Aggregate Price Effects of Institutional Trading: A Study of Mutual Fund Flow Data and Market Returns. Journal of Financial Economics 59: 195220.

Edwards, F. R., and X. Zhang. 1998. Mutual Fund Flows and Stock and Bond Market Stability. Journal of Financial Services Research 13: 257-282.

Fama, E. and K. French, 1996. Multifactor Explanations of Asset Pricing Anomalies. Journal of Finance 51: 55-83. 
Fortune, P. 1998. Mutual Funds, Part II: Fund Flows and Security Returns. New England Economic Review, Federal Reserve Bank of Boston, Jan/Feb: 3-22.

Froot, K.A., P.G.J. O'Connell. 1997. On the Pricing of Intermediated Risk: Theory and Applications to Catastrophe Reinsurance. Unpublished Working Paper, Harvard University, Cambridge, MA.

Froot, K.A., P.G.J. O'Connell, and M.S Seasholes. 2001. The Portfolio Flows of International Investors. Journal of Financial Economics 59: 151-194.

Gompers, P. and J. Lerner. 2002. Money Chasing Deals? The Impact of Fund Inflows on Private Equity Valuations. Journal of Financial Economics 55: 281-325.

Hamilton, J. D. 1994. Time-series Analysis, Princeton Press.

Helwege, J. and N. Liang. 1996. Initial Public Offerings in Hot and Cold Markets," Federal Reserve Board Finance and Economics Discussion Series working paper.

Johansen, S. 1988. Statistical Analysis of Cointegrating Vectors. Journal of Economic Dynamics and Control: 231-254.

Karceski, J. 2002. Returns-Chasing Behavior, Mutual Funds, and Beta's Death. Journal of Financial and Quantitative Analysis 37: 559-599.

Karolyi, G. A. and A. B. Sanders. 1998. The Variation of Economic Risk Premiums in Real Estate Returns. The Journal of Real Estate Finance and Economics 17: 245-262.

Ling, D.C. and A. Naranjo. 1997. Economic Risk Factors and Commercial Real Estate Returns. The Journal of Real Estate Finance and Economics 14: 283-307.

Ling, D.C. and M. Ryngaert. 1997. Valuation Uncertainty, Institutional Involvement, and the Underpricing of IPOs: The Case of REITs. Journal of Financial Economics 43: 433-456.

Myers, S. 1977. Determinants of Corporate Borrowing. Journal of Financial Economics 5: 147175.

Pesaran, H. H. and Y. Shin. 1998. Generalized Impulse Response Analysis in Linear Multivariate Models. Economic Letters 58: 17-29.

Rajan, R. and H. Servaes. 1997. Analyst Following of Initial Public Offerings. Journal of Finance 52: 507-529.

Remolona, E.M., P. Kleiman, and D. Gruenstein. 1997. Market Returns and Mutual Fund Flows, Federal Reserve Bank of New York Policy Review: 33-52. 
Sa-Aadu, J. and J.D. Shilling. 2001. Dividend Policy, Capital Gain Realizations and REIT Value. Working Paper, March 2002.

Sirri, E. R. and P. Tufano. 1998. Costly Search and Mutual Fund Flows. Journal of Finance 53: 1589-1622.

Sims, C. 1980. Macroeconomics and Reality. Econometrica, pp. 1-49.

Stoughton, N.M., K. Wong, and J. Zechner. 2002. IPOs and Product Quality," University of California at Irvine, working paper.

Stulz, R. 1999. International Portfolio Flows and Security Markets. In Feldstein, M., (Ed.), International Capital Flows, National Bureau of Economic Research, forthcoming.

Tesar, L. and I. Werner. 1995a. Home Bias and High Turnover. Journal of International Money and Finance 14: 467-492.

Tesar, L. and I. Werner. 1995b. "U.S. Equity Investment in Emerging Stock Markets. World Bank Economic Review 9: 109-130.

Warther, V.A. 1995. Aggregate Mutual Fund Flows and Security Returns. Journal of Financial Economics 39: 209-235.

Warther, V.A. 1998. Has the Rise of Mutual Funds Increased Market Instability? Brookings Papers on Financial Services, The Brookings Institution. 


\section{Figure 1}

REIT Flows

Panel A: Gross Equity Flows (billions \$)

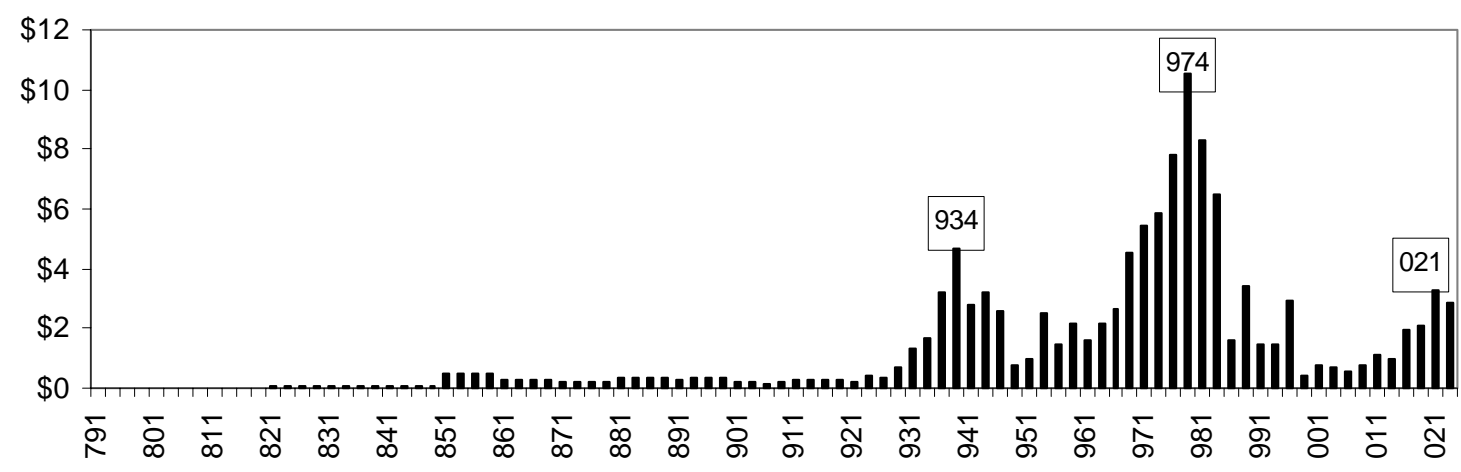

\section{Panel B: Net Equity Flows (billions \$)}

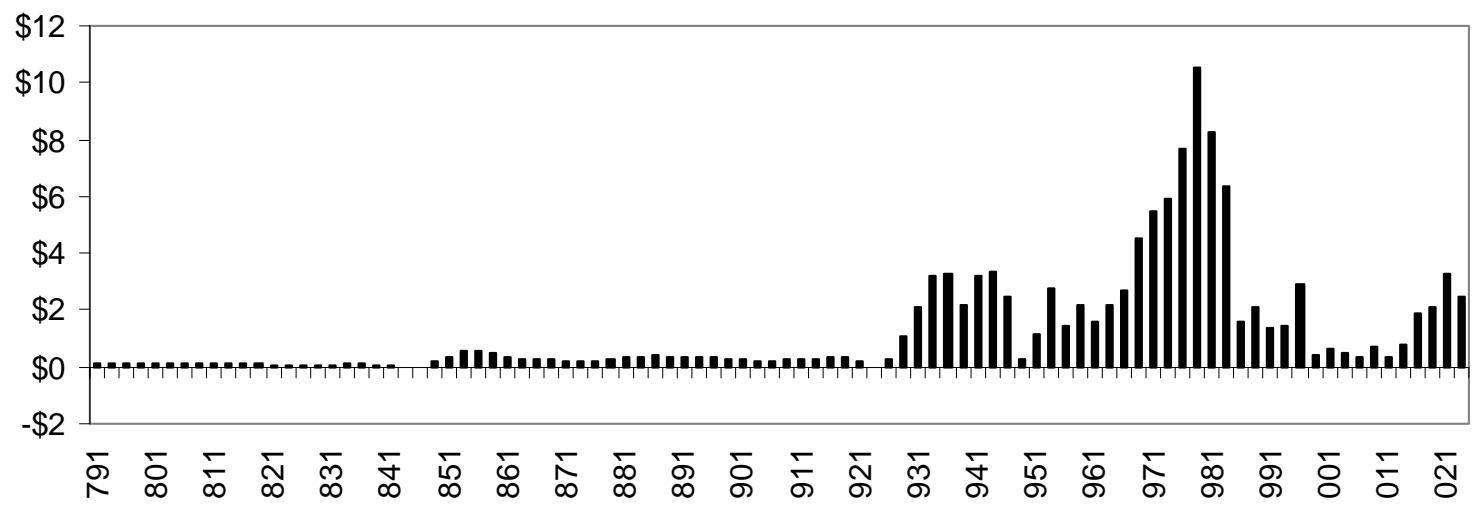

Panel C: Net Total Flows (Debt + Equity) (billions \$)

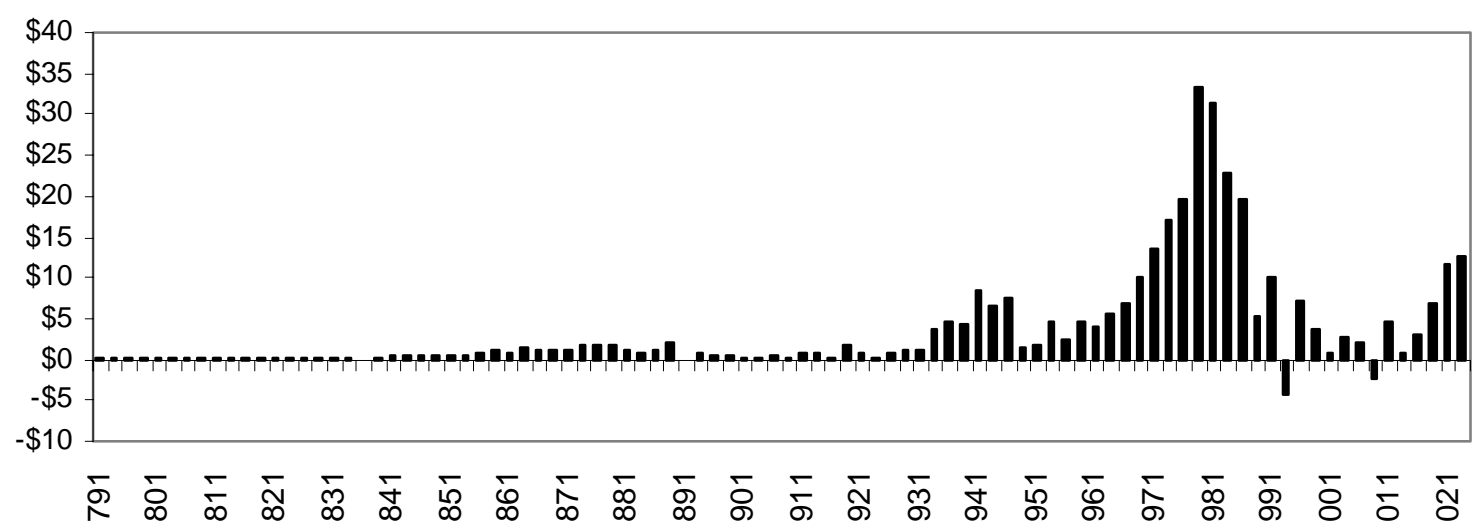

Gross equity flows (Panel A) include IPOs and secondary offerings of common or preferred stock. Net equity flows (Panel B) equal gross equity flows minus equity retirements. Net total flows (Panel C) equal net equity flows, plus net debt issuance, plus the change in miscellaneous REIT liabilities. 
Figure 2

Cumulative Flows (billions \$) and Returns

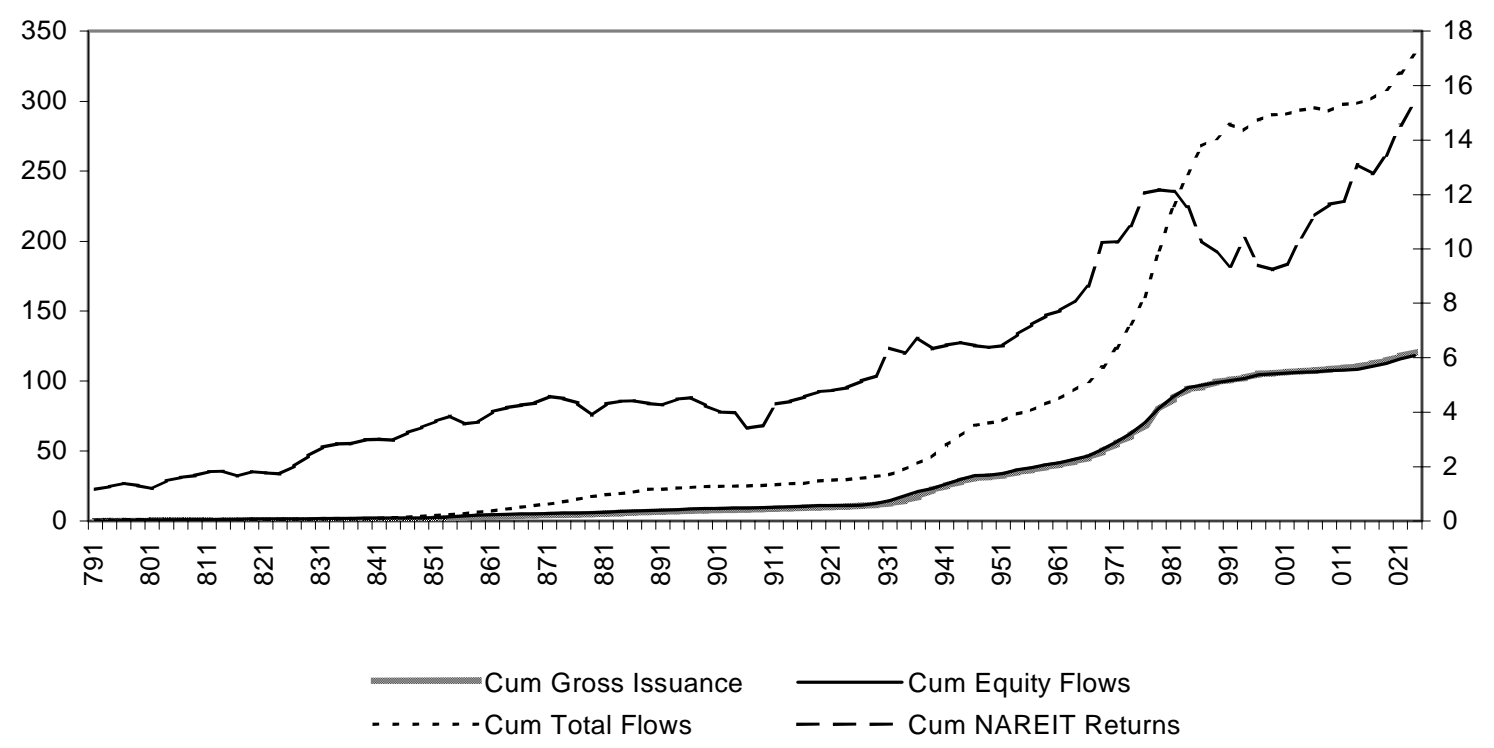

Figure 3

Net Equity Flows: billions \$ and as a \% of REIT Stock Market Capitalization

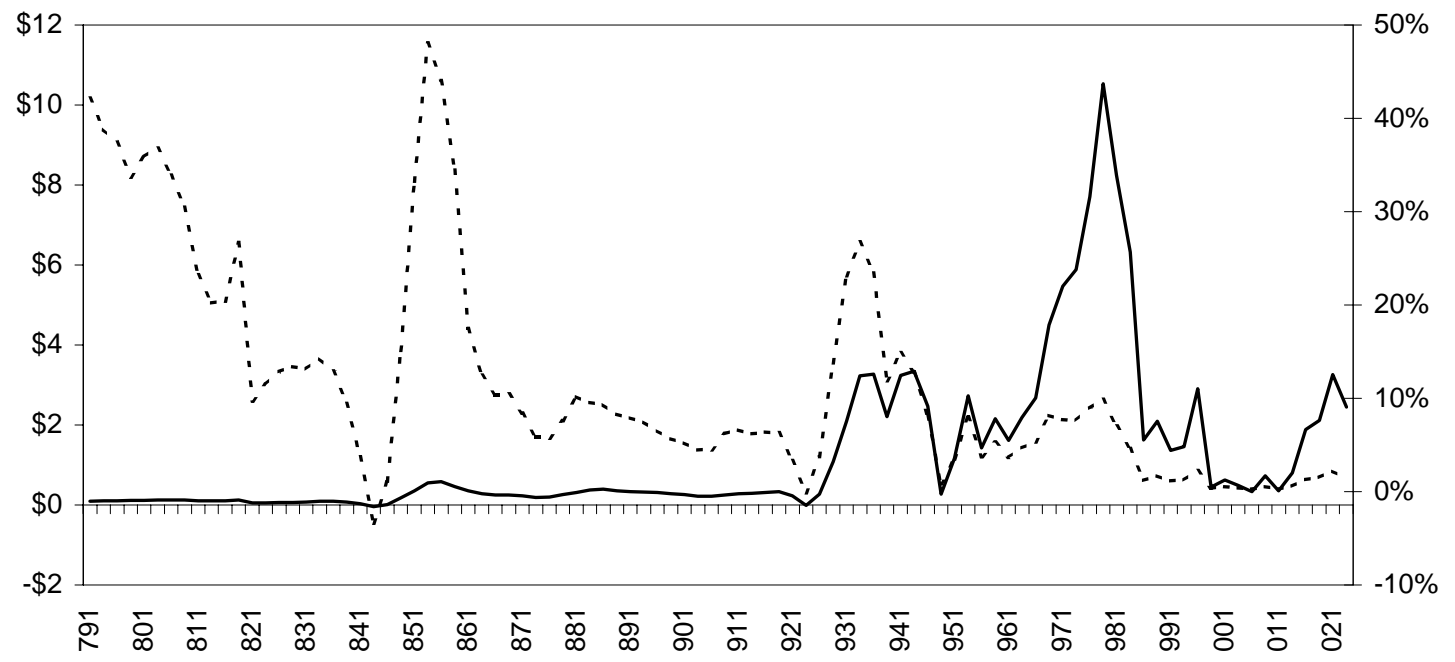

_. Net Equity Flows in Billions

.... - As a \% of Mkt Cap 
Figure 4

NAREIT Returns and Equity Flows to Market Capitalization

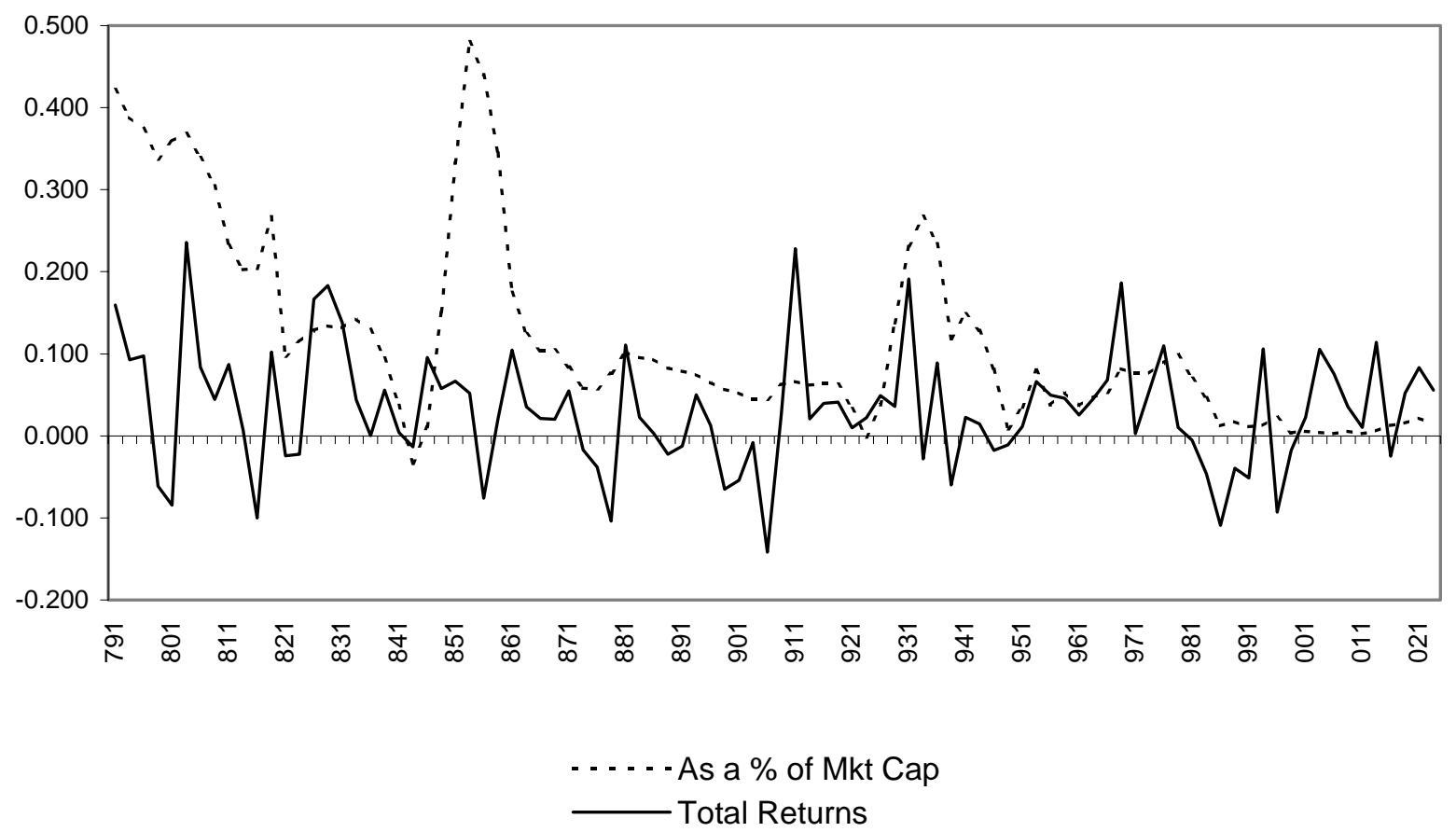




\section{Figure 5}

\section{Impulse Responses from Vector Autoregressive Model (Seven-Factor) Post Period: 1993(Q1) - 2002(Q2)}

Response to Generalized One S.D. Innovations
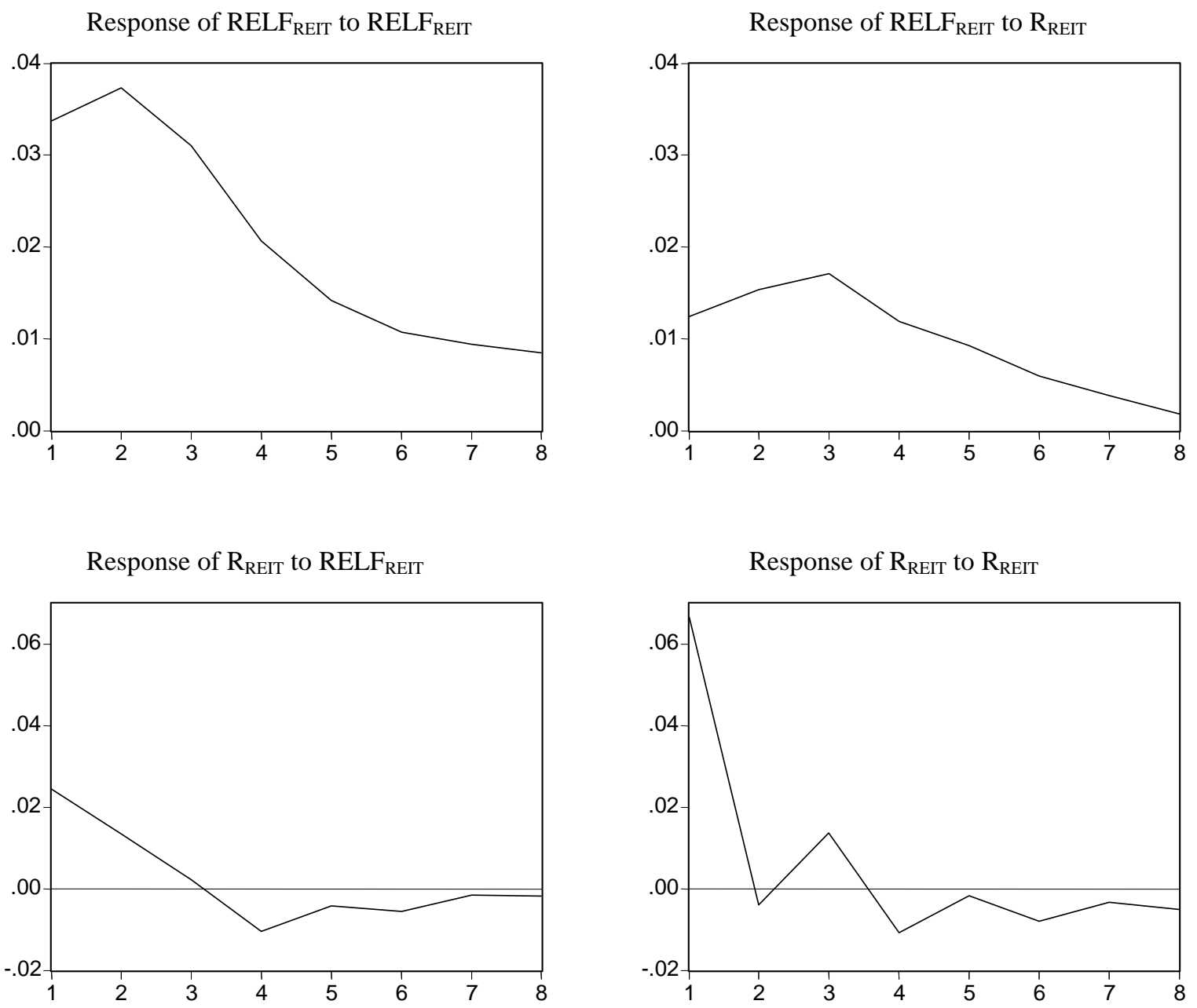


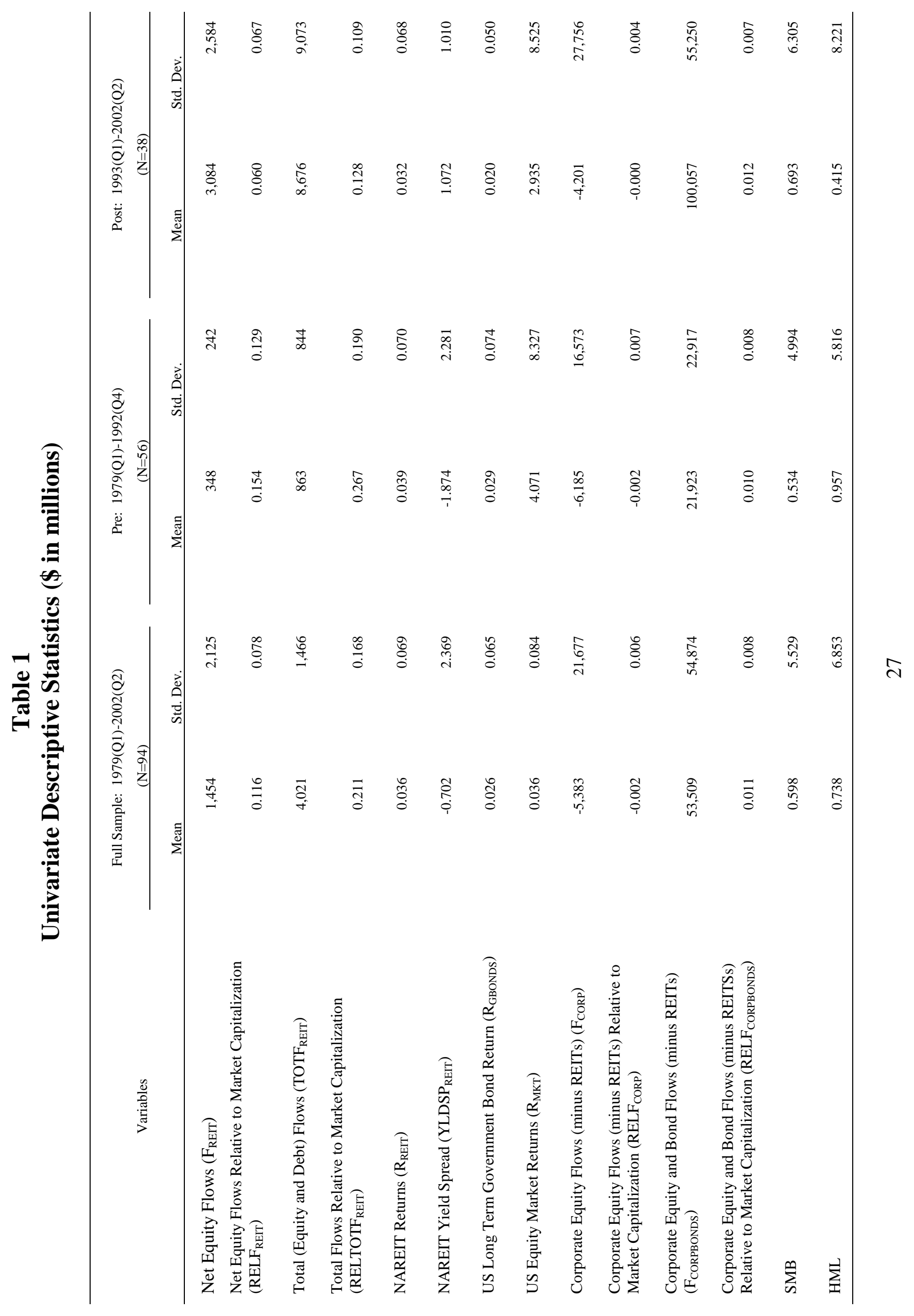




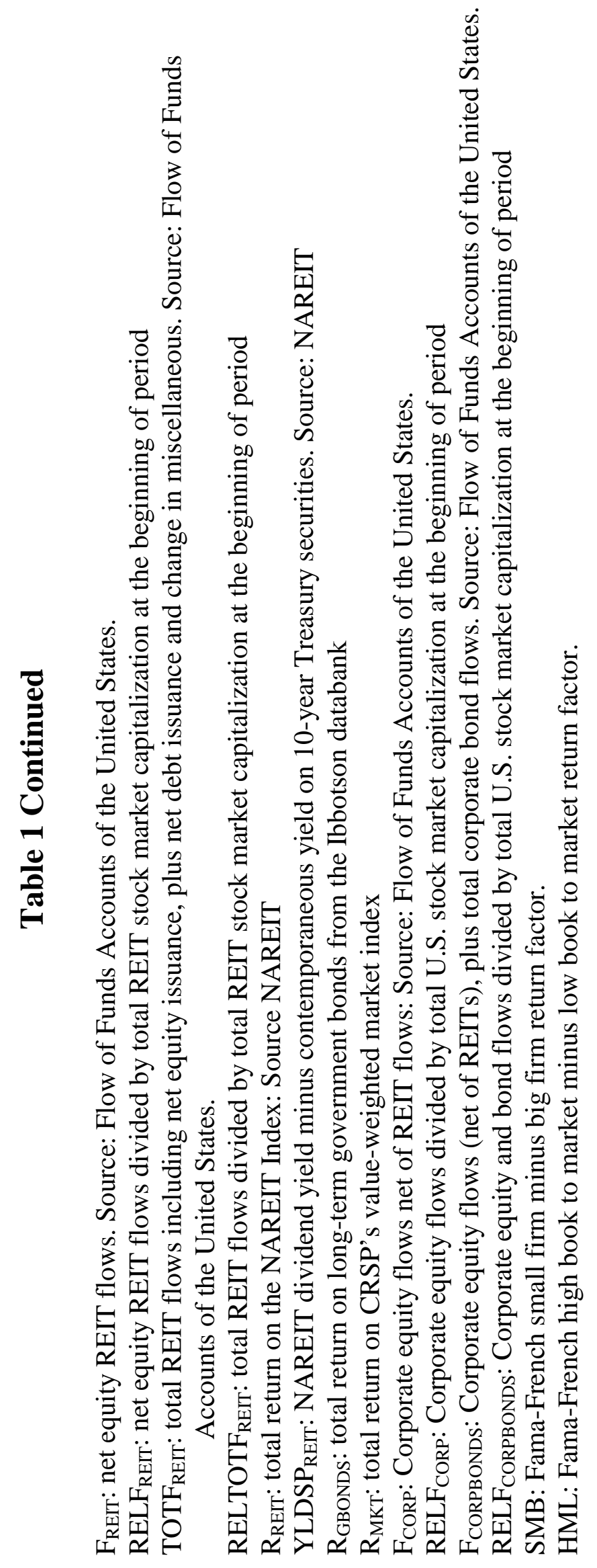




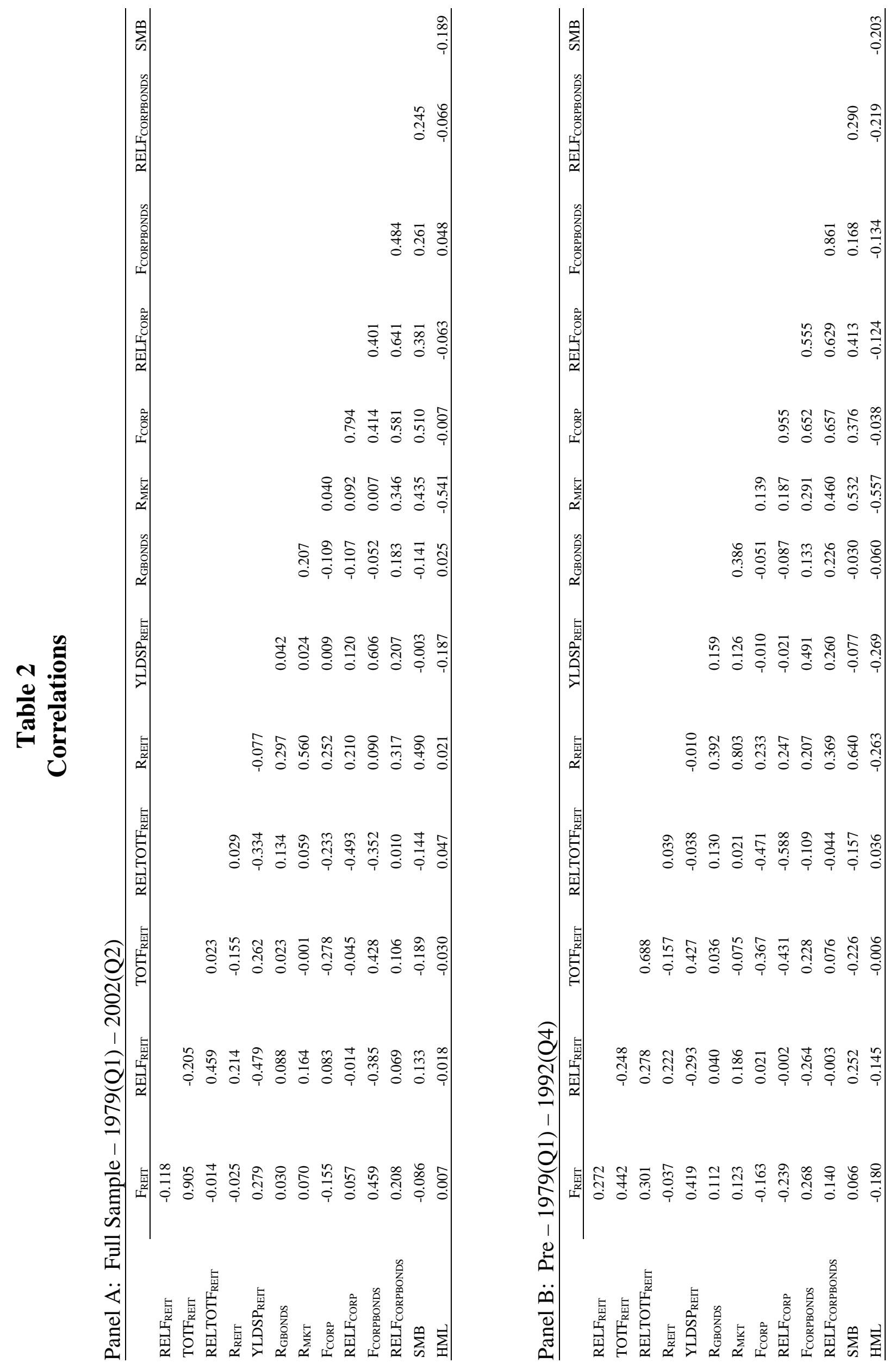




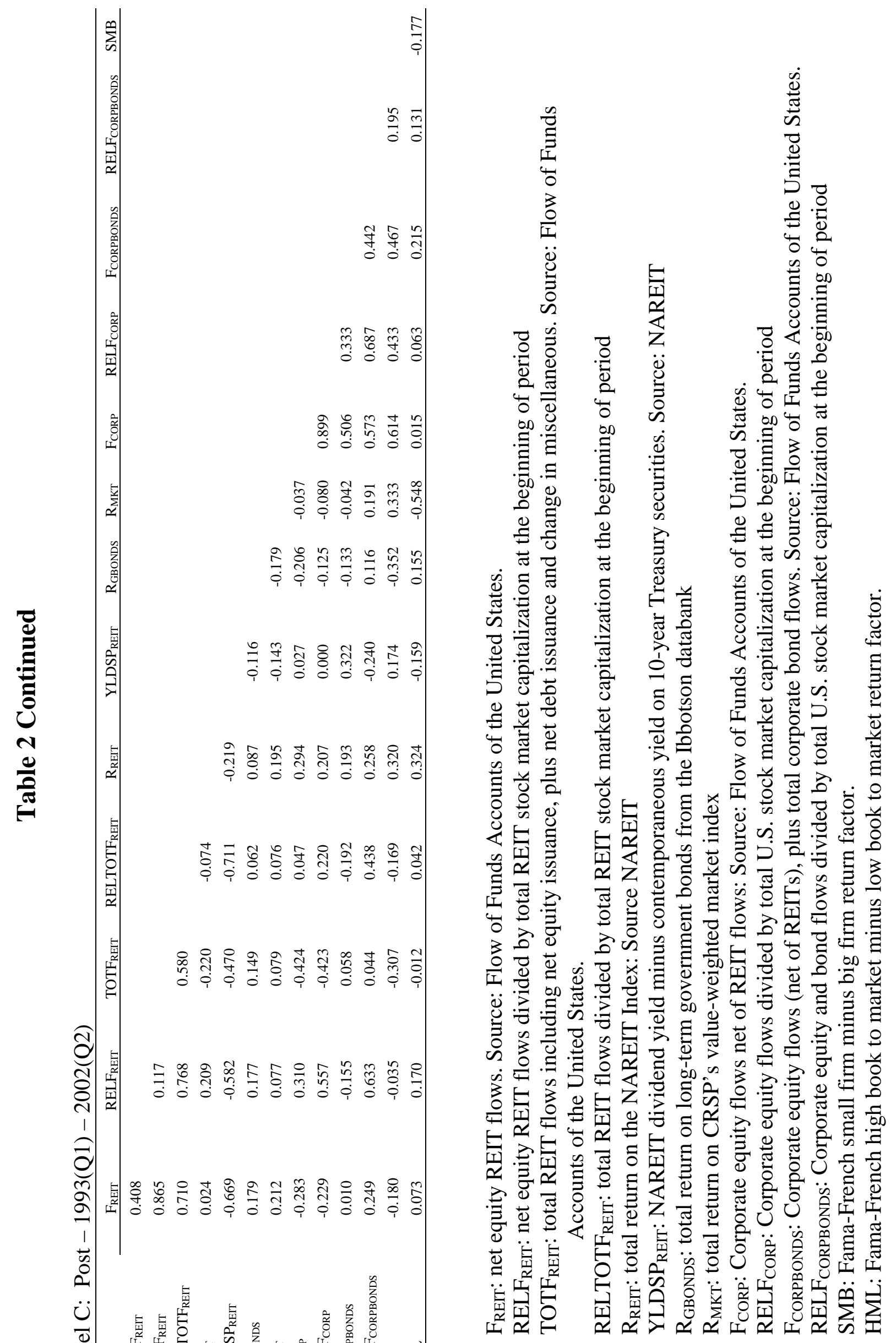




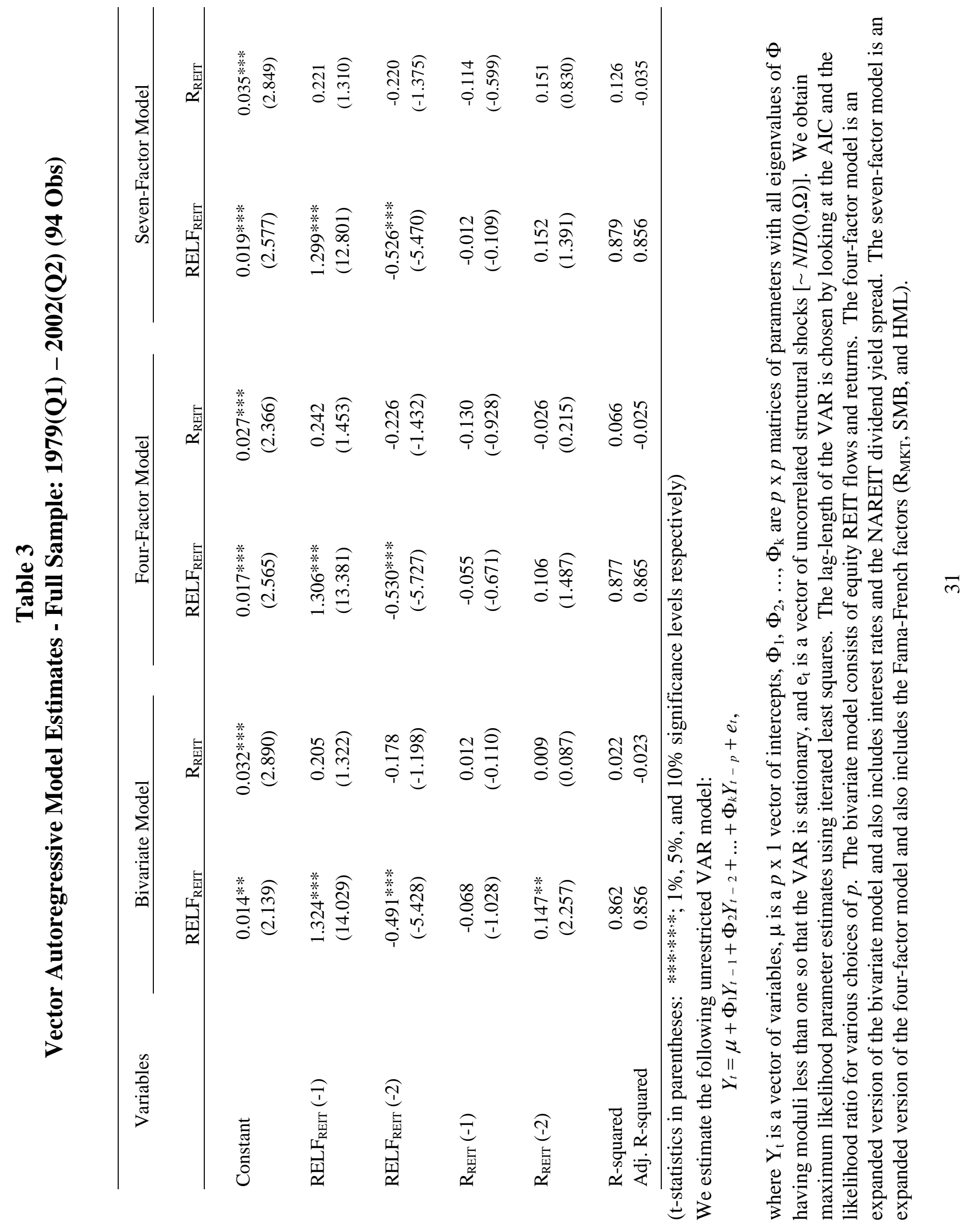




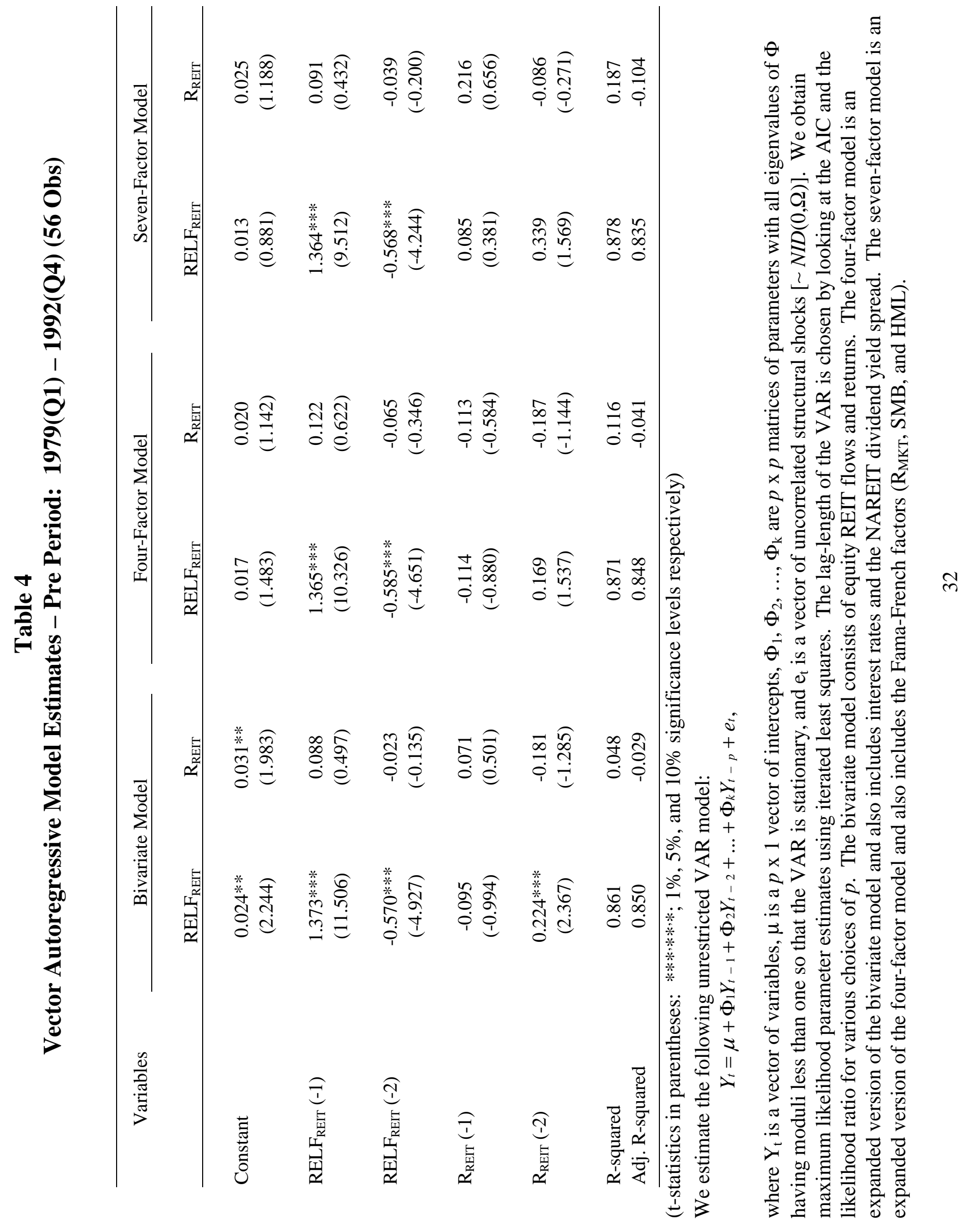




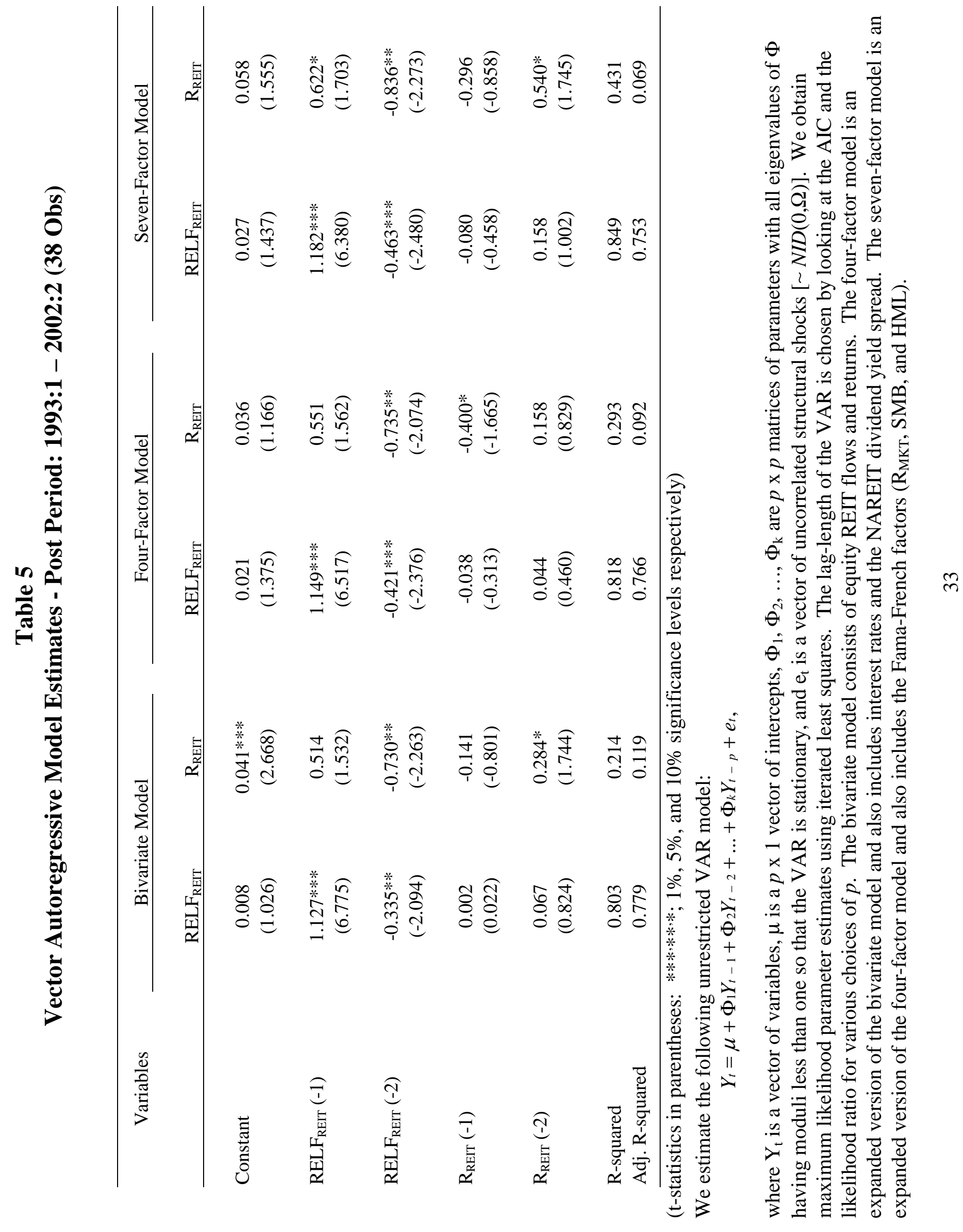



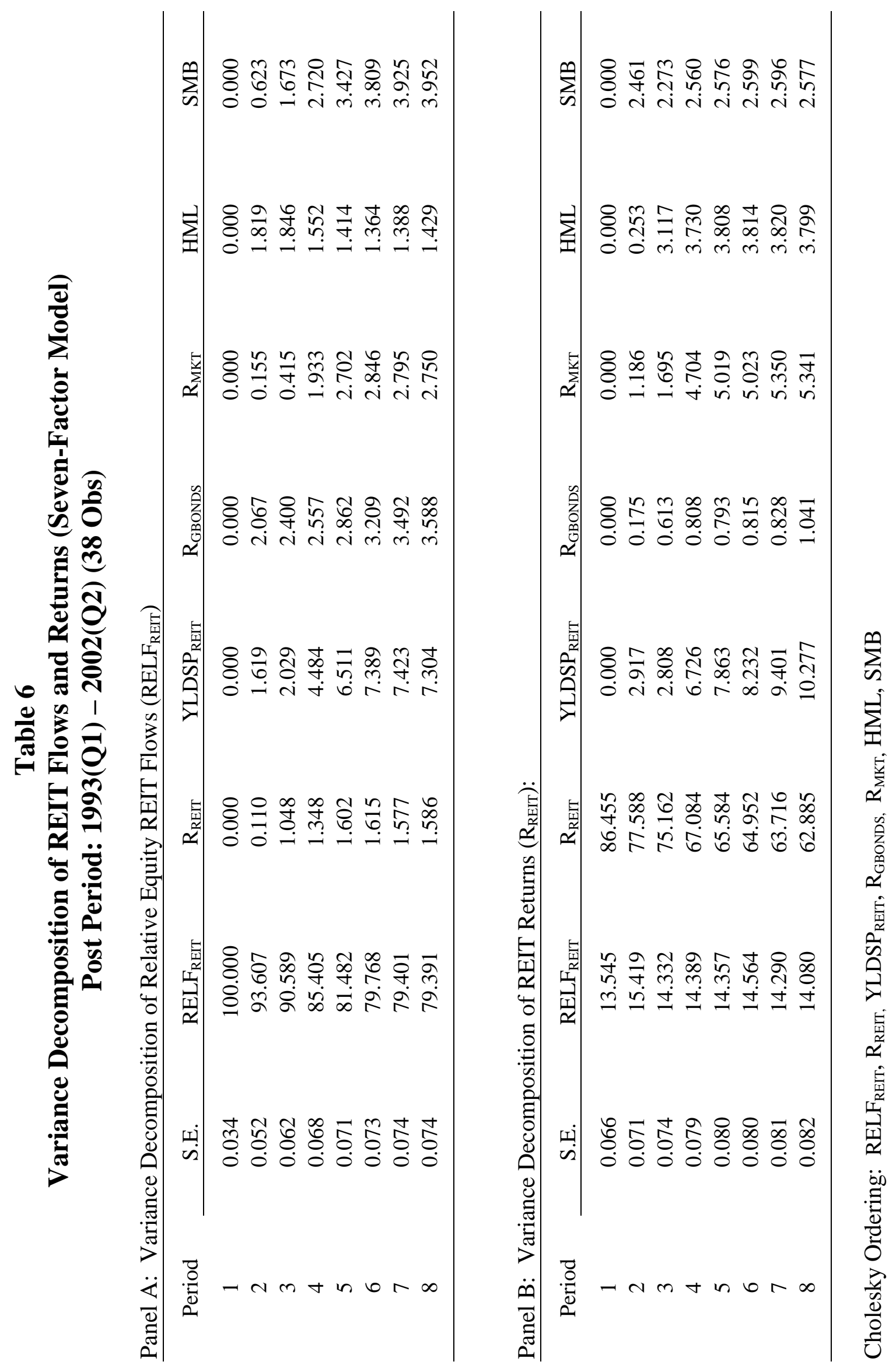